\title{
Concepts of Criminal Law and Representative Reductions $^{1}$
}

\author{
Af Jørn RT Jacobsen ${ }^{2}$
}

\begin{abstract}
This article explores the relationship between the criminal law and its surrounding fields of knowledge. It focuses on the necessary interaction between the criminal law - with its requirements of simplicity and applicability - and the complexity found in other scientific disciplines that the criminal law in some way relates to. The article introduces the notion of "representative reduction" as a means for understanding this kind of interaction. By using this notion, the article provides an account of how the criminal law is structurally related to its surrounding fields of knowledge. Furthermore, it argues that it can contribute to the interaction between the criminal law and these fields in order to improve the content of the criminal law. The notion of representative reduction is in particular exemplified and discussed in relation to criminal responsibility for youth. The article also addresses some additional aspects of the overall subject, such as the problem of injustice stemming from the use of representative reductions and the role of the criminal law science in regard to the use of representative reductions.
\end{abstract}

\section{Introduction}

In the following, I will provide some reflections on the "nature" of the concept of crime. More precisely, I will address the specific challenges that arise from the tension between on the one hand, what we may term a pre-legal complexity and, on the other, the need for a distinct kind of legal simplification of this complexity. The problem to be addressed could also be formulated as a question regarding the relationship between substantive criminal law and its surrounding knowledge fields, like criminology, moral philosophy, psychology and sociology. ${ }^{3}$ Seen apart from in particular Lasson's and Hagerup's contributions from past ages, a characteristic of the Norwegian criminal law science is a certain disinterest in surrounding knowledge fields. ${ }^{4}$ The pragmatist tradition dominating this discipline can in general be said to have dealt with this challenge by restricting the attention to the legal system and the courts in particular, a solution that entails some problems. In particular two related problems are worth emphasising. 
First of all, a core aspect of modern society is its differentiation into different complex subsystems, like economy, politics and law. A result of this is also the differentiation of knowledge within these subsystems. One could then expect that the world as one sees it is to a large extent the world as seen from ones specific point of view, a basic hermeneutic insight. Ergo: the more differentiated law is in modern society, the less reason one has to trust the law itself as a reliable source of knowledge of reality in itself. ${ }^{5}$ Certainly, in regard to understanding law as part of reality, it is to a large extent necessary to see it "from within". But one can't expect to capture the whole of reality from that point of view: Even if the legal system may have the strength of having over time closely interacted with society by means of concrete cases being brought to the court for adjudication, thus giving the system an empirical basis for making judgments, ${ }^{6}$ there is still a significant risk that the opinions produced are "adapted" to the existing legal knowledge. Secondly, and related, another problem of the pragmatist approach is that it seems to disregard the amount of knowledge generated within other scientific disciplines. Given the differentiation also of the scientific disciplines, we face a quite complex set of different (to some extent competing) conceptual schemes seeking to capture parts of reality. In this perspective, there is no principled difference between law, sociology, psychology or even philosophy - it is, as I will return to, a matter of different subject-formed perspectives and to some extent different methods applied in the attempt of capturing (a part of) reality. In sum: this current disinterest in the Norwegian criminal law doctrine seems to be contradicting the pragmatist claim to be in close interaction with society or reality as expressed by slogan-style expressions as "[w]e leave the concepts, and proceed directly to reality". 7 If we maintain that law should be in contact with (a nonlegal) reality, it seems instead fruitful to start out from that some kind of a more complex interaction between the legal concepts and the surrounding (non-legal) sources of knowledge.

\section{The Complexity of Legal Concepts}

The concepts of criminal law have a complex character. On the one hand, it is clear that the concepts of criminal law frequently have some kind of pre-legal origin, or at least they do have their corresponding concepts in other fields of knowledge. It is sufficient to mention concepts like responsibility, intent or attempts. It is indeed difficult to find concepts in criminal law that are legal sui generis, i.e. that do not seem to have their origin outside law (the use of terms related to the law, like in "legality", "Rechtswidrigkeit", "Rettsstrid" or similar, is not decisive for a concept being sui generis or not.) In "prescription" one has perhaps 
found an example. ${ }^{8}$ Given this pre-legal origin of core concepts in criminal law, many hold it as necessary that these concepts at least in some manner build upon their pre-legal background. Illustrative is the great interest in philosophy found in Western criminal law literature. It is difficult for instance to understand the legal concept of intention without taking into account the (use of the) concept of intention as part of the moral language. (Thereby I do not imply that the legal concept of intention can be fully reduced to a pre-legal phenomenon. That is obviously not the case.) And Hagerup, for instance, strongly emphasised the necessity of psychological insights in order to capture essential aspects of criminal law. The opposite view has of course also its prominent proponents. Still, this pre-legal orientation is, given that one starts out from the principle of guilt, or a "personal-functional" position, and that I think one should do, well-argued. Generally, if one wants to set up (legal) criteria for making judgements on other people's actions, one has to start out from some kind of pre-legal understanding of what is involved in performing an action. Hence, even if the interest in the concept of action may from time to time vary, this concept could not at any time be allowed to go fully out of style.

On the other hand, legal concepts are at the same time legal concepts and as such distinct in regard to moral philosophical or psychological concepts and so forth: The concepts of criminal law do have their distinct characteristics that distinguish them from their pre-legal basis. In this regard, the most basic characteristic is that the concepts of criminal law have their location within a legal system that is fundamentally orientated towards the binary code of legal/illegal. I will not go much further into the nature of this binary code and its background here. ${ }^{9}$ Briefly, the distinction between legal and illegal excludes the possibility of modifications ("a-bit-illegal") within the legal system. If something is not illegal, it is legal, however illegal-like it is. This core aspect of law is closely related to the possibility of filling the core functions of the legal system, including the criminal justice system. For instance, one such function is to insert "predictability" in different social spheres in regard to what one is allowed to do and what one is not allowed to do (without facing certain consequences). The possibility of filling this function is to a large extent dependent on unambiguous rules and a complex institutional structure where, in case of disagreement, certain decisions-makers have a final say on the interpretation and application of the rule - and does so within reasonable time. (In a sense, one may therefore say that the subject we address is part of the relation between substantial criminal law and criminal procedure, and then in particular the impact of the latter on the former. ${ }^{10}$ ) In this regard, there are clear differences to other norm-systems, for instance morality. 
Before proceeding, we should, however, somewhat nuance this starting point by pointing to that the binary code is to a large extent capable of containing mediating sub-distinctions, for instance between "illegal, but not criminal" and "illegal and criminal", or between "not criminal/justified" and "not-criminal/excused", without violating the basic code itself, a point that I will return to. Also, the principles of sentencing mediate the rigidity of the legal code, to some extent dependent on which principles of sentencing that one follows.

In ordinary life, of course, the idea of a binary code in regard to for instance the development of youths and their capacity for responsible action would indeed be comical. Here, we can cope very well with seeing responsibility for youths as a long-time and complex process, which includes also individual experiences and the present state of social institutions like education, where one (normally) develops from being a child into a fully responsible grown up. The complexity of this process is well documented in child- and youth psychology. ${ }^{11}$ Also ascription of moral responsibility is usually adjusted in accordance with this complexity. However, the criminal law could hardly function with such a solution. In criminal law, we instead find, usually motivated by "legal technical reasons", a quite strict line - in Norway, according to section 46 in the Criminal Code of 1902,15 years. $^{12}$ This line allows for no further discussion on the factual capacities of the individual; everyone that is 15 years or more is considered to have the sufficient responsibility-capacity, and all those that are not yet 15 years do not have it. It could here be mentioned that the Criminal Code of 1842 made use of a more differentiated solution: Here one had an absolute limit at the age of 10 , while, in regard to children between 10 and 15 years, one was supposed to individually consider whether he or she had "realised the criminal nature of the act", i.e. to make a judgement on the specific moral capacity of the individual. ${ }^{13}$ It does not take much to see the problems that arise from such a legal criterion, in terms of difficulties for the court to judge on the basis of such a criterion, but also the accompanying potential for power-abuse and inequality. Or stated differently, the only way to handle such a complex reference would be to exchange it into some more general standards for making the judgement. As this example illustrates, this tension between a pre-legal complexity and the legal need for simplification is particularly pressing within the category of "guilt" or "personal" requisites for criminal responsibility, in particular those that relate to the constitution, capacities, character or what term we here should apply, of the individual. 


\section{Introducing "Representative Reductions"}

\subsection{Starting Points concerning Representative Reductions}

How then to mediate between a pre-legal complexity and the criminal law's seemingly profound need for a more precise criterion ? $^{14} \mathrm{~A}$ basic starting point, it seems, would be "representative reductions": We must, on the one hand, precisely reduce the pre-legal complexity - itself resisting a simple and strict categorisation - into an operational criterion that satisfies the basic binary code. ${ }^{15}$ By separating between not having responsibility-capacity and having it by means of a strict age limit, we make a, in this case quite far-reaching, reduction. In the literature, as in Andenæs, this is explained by references to "legal technical reasons": "There is of course no change of personality in the moment a person is 15 years. And the time of maturity differs from individual to individual; a boy or a girl at 13 or 14 years may have reached the same level of maturity as somebody else at the age of 15 or 16 . But there has to be one limit, and due to legal technical reasons this limit is set at a certain age without any question of level of maturity."16

This explanation of "legal technical reasons" could clearly be taken as referring to the mentioned legal code of legal/illegal (criminal/not criminal). But why there must be a limit is only the first question. The additional question is why the limit is, or should be, set as it is. If the need for a clear criterion for deciding between cases was the only matter, then this criterion could be satisfied by a huge number of solutions here (5 years, 10 years, 15 years and so on), and critique of some solutions, as when Per Ole Träskman criticised ECHR's acceptance of two ten years old kids being held criminal responsible for murder in England, would not be particularly meaningful. ${ }^{17}$ But clearly there is more at stake than just having a strict line in itself.

In order to identify why the line is set where it is, we should understand the solution as an attempt to in some manner make the reduction mirror or represent pre-legal knowledge on the subject. Legal thinking draws here upon on a common feature of human intellectual life. The mechanism described is exclusive to the legal system, but is rather a more common feature in human life, i.e. reduction of complexity. To make an example (also of relevance to the criminal law): In daily life we frequently ascribe each other certain characters, both as individuals (John is a kind man, Tom is a devil, Anna is lovely) and as groups (people in Bergen are loud speakers, youths today are rude). The ascription of a certain character to someone is usually an operation of a representative reduction. For instance, when ascribing John the character of kindness, the case could be that one even has some experience of him not being kind (losing his temper, swearing, and when drunk, he even hit his ex-wife's new man), but one disregards this 
information in ascribing him the character of kindness due to experience of John taking care of his sick mother, being a good father to his kids, showing care to animals, donating money in emergencies, being a dedicated and competent pediatrician, etc. The example illustrates at the same time that a representative reduction is not the same as inductive reasoning (going from "every swan I have seen have been white" to "all swans are white"). Even if both are a kind of generalisation, the inductive inference is (disregarded the problems connected with such reasoning) dependent on the premises not being changed (the observation of one or more black swan(s)). A representative reduction has rather the structure similar to

$\left(\mathrm{y}_{1}+\mathrm{x}_{1}+\mathrm{y}_{2}+\mathrm{y}_{3}+\mathrm{y}_{4}+\mathrm{y}_{5}+\mathrm{y}_{6}+\mathrm{x}_{2}\right)=\mathrm{y}$

$(\mathrm{y}=$ good deed, $\mathrm{x}=$ wrongdoing $)$

Even if one adds another $\mathrm{x}$ to the premises, the outcome may still be $\mathrm{y}$. But also, the introduction of one single $\mathrm{z}$ (= serious wrongdoing) may change the outcome: A mother has done much good to her child ("a good mother")), but then at intentionally commits a serious crime to it, for instance an incident of sexual abuse. This added fact is capable of changing the outcome ("not a good mother"). The representative reduction can in other words not be understood purely quantitative. One could say that representative reductions are similar to what in ordinary language is termed an (adequate) impression of something.

\section{2. "Programming the Code"}

In order to make (or understand or evaluate) a representative reduction we are first of all in need of a "perspective", a "programme" for the legal code, in order to identify the relevant pre-legal material. There are basically three different lines of argument, each dependent on a motivation of setting the age limit at a certain age. One can claim 1) that the age limit is motivated by arguments of general deterrence, for instance that one has to be more than 15 years old to be affected by the threat of punishment, or 2) that the age limit is motivated by humanitarian arguments, i.e., one experiences it as brutal, damaging, insensitive (etc.) to punish children and youths not yet aged 15, and hence does not want to do it (even if this group of offenders are principally criminally responsible), or 3) that children and youth younger than 15 lack prerequisites for being held criminally responsible in the sense that this is a distinct kind of moral responsibility.

Now, from my point of view, the only sustainable argument is the last one. The argument of general deterrence is frequently used in attempts to motivate this 
and similar criteria for criminal responsibility. The underlying premise is that some groups (youths and insane persons) cannot take the threat of punishment into account at the time of acting, and that the threat thereby is useless and, given the underlying utilitarian aim of general deterrence, not motivated. This is however, as Hart made clear in regard to Bentham's similar argumentation, a non sequitur. ${ }^{18}$ Even if it these persons were not capable of taking the threat into account at the time of action (a questionable empirical premise in regard to youths at least), this does not mean that one would not get an increased overall general deterrent effect by punishing also youths and insane persons.

The second line of arguing, the argument of humanity, is in itself valid. And it is also frequently used in current discussions on juvenile justice. But it is not a quite satisfactory explanation of why one has used such a general lower age limit for being held criminally responsible and punished. Or to put it somewhat differently, the argument of humanity may probably go as a motivation for not imprisoning a youth, but it is more difficult to see why it is inhuman to fine them. One could make use of similar solutions as in tort law without the system being "inhuman" for that reason.

The strength of the last line of arguing does not only stem from the insufficiency of the two other lines of arguing. Rather the argument of a lacking prerequisite for criminal responsibility seems to have some kind of priority in regard to the two others. Unless one accepts a utilitarian point of view, the argument of utility must be qualified or limited by the person being punished deserving punishment. ${ }^{19}$ And the same goes for the argument of inhumanity. It seems strange to argue for abstaining from punishing due to arguments of humanity if one does not acknowledge the right to punish the relevant (group of) individual(s) in the first place. This argument is closely tied to a certain concept of criminal responsibility, i.e. one starting out from the principle of guilt.

The principle of guilt implies that there are close references between moral and criminal responsibility. In this text, the principle of guilt is taken as a core premise for the entire understanding of criminal law. The argument in the following will therefore start out from this principle, a starting point that will colour the discussion of the representative reduction. But it should be added that speaking of representative reductions is not conditioned by this starting point. Also, if one rather advocates another line of argument in regard to the motivation of the age limit, the need for making a representative reduction remains (at which age do one in general become able to take in the threat of punishment into account, or at which age is it no longer in general inhuman to punish someone?). In regard to 
these questions the material is also so complex that one does not avoid the reduction and the claim for it being representative.

\subsection{Making it Representative}

\subsubsection{Basic Starting Points for Making it Representative}

By now we may return to the representative reduction concerning youth's (prelegal) capacities for responsibility. Here, there are several sources and viewpoints to consider, for instance child- and youth-psychology, sociology and (empirical) criminology. And also the legal system has its own knowledge of the subject that is to be taken into account: To the extent that the courts are assigned to complete the rule, as they frequently are assigned to do in regard to concepts within the concept of crime, like for instance the concept of mens rea, they do so partly by reference to general knowledge held by the decision maker herself who is not only a system participant but also a person in itself, and partly by reference to the experiences of the legal system itself. I will return to these different sources of knowledge below. The important point so far, is that in regard to the capacity of youths to be responsible for their actions, there is massive material giving a quite complex scheme of viewpoints that reject any simple answer as to whether or when youths are responsible for their actions. And it is of importance to underline that we are not capable of fixing one point or one perspective as the representative or the "original" one for the pre-legal sphere. Rather we find a complex of different perspectives or theories that sometimes underpin each other, sometimes overlap and sometimes even contradict each other. The "ordinary life experience", in Norwegian criminal law literature often expressed as "common sense" is also only one such perspective.

How then to perform the reduction in order for it to be representative? "Representative reductions" are not a method to be operated like a mathematical formula: Criminologists and psychologists would rightfully be sceptic about the possibility of making such a (strict) reduction of their knowledge on the subject, not to mind when grouped together with others! On the other hand, new or revised viewpoints in these discussions cannot simply be "implemented" into the system of legal knowledge which is dependent on a certain kind of spatiotemporal stability (see further below). What is addressed here is instead (first of all) a way to conceive the structure between the legal discourse and criminological, psychological discourses and so on, a structure that is complicated by the role of ordinary life, also as a possible mid-station for this exchange. ${ }^{20}$

But even if we cannot think in terms of a precise method, there is also a basic practical potential in "representative reductions". At the same time as it allows us 
to respect the increasingly distinct and non-transferrable complexity of different discourses in regard to each other, it also makes it possible to evaluate the solutions in criminal law, and it makes it meaningful for us to let other knowledge fields "irritate" the law in order for a successive adjustment of the solutions of criminal law into a more "representative" solution - but still in law's own terms. Hence, representative reductions are not only a descriptive enterprise, capturing a mechanism already in play, but also a normative enterprise, as it by the extrapolation of this mechanism seeks to contribute to the increased and improved use of it.

The underlying premise here is that despite law's claim of making representative reductions of the pre-legal complexity, the legal system is not always successful in performing its representative reductions in a proper manner. Unsuccessful representations, or non-representative reductions, are also found within the legal system. ${ }^{21}$ Critical viewpoints such as Träskman's presuppose the (potential) existence of such non-representative reductions. The occurrence of nonrepresentative reductions is, however, not a problem for the idea of representative reductions in itself, but only for the way this operation has been preformed. Even though there is in law a legitimate time-delay-mechanism in regard to the development in surrounding fields of knowledge, it is obvious that the legal system does not always respond quickly enough to such changes - either at a more terminological or also at a more substantial level. This tendency has, in part, to do with the fact that law is a knowledge system with internal requirements of coherence, but can also partly be ascribed to the fact that such an update of the legal system requires the activation of the legislative procedure, and, in consequence, requiring both political support and financial means. But sometimes it is being done. One example in this regard is the update on the Norwegian rules on what that is to count as sufficient mental illness for being excused for a crime. ${ }^{22}$

Despite the lack of a "method" in regard to the practical use of the notion of representative reductions, certain guiding principles, at least in an ideal situation, can be listed. Ceteris paribus

- experiences from ordinary life have a high value due to their empirical and individual character (a cognitive mechanism);

- scientific investigations have high value due to their methodological qualities (rationality-principle 1);

- scientific investigations that take place within a discipline that is committed to studying the relevant object should have higher value than investigations that take place within a discipline that is not committed to the relevant object (psy- 
chological studies of psychological elements have higher value than investigations in law touching on psychological premises in regard to the psychological elements (rationality-principle 2);

- knowledge held in one field of science has higher value if it is supported by the knowledge held in other fields of science (rationality-principle 3, in particular to be combined with principle 2);

- recent scientific investigations have higher value than older scientific investigations (rationality-principle 4);

- knowledge valid over time have higher value than knowledge recently developed (rationality-principle 5);

- A scientific investigation has higher value the more often it has been confirmed by other investigations (rationality-principle 6).

The situation is, however, not always that law is not-up-to-date in regard to knowledge produced in other fields of knowledge. Sometimes the understanding of a phenomenon in other disciplines is non liquet, while law (as a political instrument) is in dire need to progress the scientific discussion and make a stand on a certain problem (for instance certain environmental problems). How the criminal law can adequately perform its representative reductions in regard to phenomena which are clouded by uncertainty in other sciences, are a complex matter that is not possibly given a simple answer to. As a starting point: There will most often at least to some extent be some kind of uncertainty in the scientific knowledge production to be taken into account in the law's representative reductions. The number of possible or acceptable legal solutions will be as a starting point proportional to the degree of doubt concerning the phenomenon (given that the legal decision could not be suspended), a starting point that must be supplemented by for instance a risk-principle and more.

\subsubsection{The Temporal Dimension}

This operation of representative reductions within the legal system cannot, however, be fully conceived from such a spatial (at a certain point of time knowledge representative) dimension only: To this, we have to add the important temporal dimension. Here, it is useful to start by pointing to the fact that, without presupposing a stream-line improvement, different kinds of such sources of knowledge continuously develop and (hopefully) improve in regard to the opinions held. This is in particular the case for the different scientific disciplines. At the same time, new insights are frequently overemphasised; what was first propagated as a "new truth" came rather to be an additional aspect of the existing knowledge that 
makes the existing knowledge richer, more nuanced and more complex, and even rejects some parts of it. The humanities and the social sciences have proved less capable of resisting this tendency, with several examples of scientific enthusiasm over new insights being turned into an undisciplined "complete domination" of this viewpoint. The fate of the postmodernism and its different branches is the most recent example. ${ }^{23}$ The legal science is of course not unaffected by such intellectual trends. Also the history of the concept of crime mirrors the same overenthusiasm and one-sidedness.

For the legal system, however, such swift and extreme shifts of opinions pose a potential problem: Law is given its normative and system-theoretical requirements necessarily dependent on a greater stability, often expressed in terms of a kind of "conservatism", which forces it to maintain more reluctant towards such paradigmatic shifts. And this, it should be added, should not only be seen as a weakness of the legal system. It thereby also becomes more immune to hasty and ungrounded radicalism. But the lack of openness does create challenges in regard to the communication with other knowledge systems; it is by means of this "conservatism" that the legal system seems to have some difficulties in interacting with or exchanging knowledge with other knowledge systems. The notion of (spatiotemporal) representative reductions of the existing available knowledge is the solution of the legal system to this problem.

\section{The General Relevance of Representative Reductions: The Concept of Person}

Now the example of the age limit for criminal responsibility for youths is a very clear-cut one, one that one does not find too many examples of. However, it seems as the phenomenon of representative reductions itself is of more general relevance to concepts of criminal law, even if in more subtle ways. Such reductions can for instance be claimed to be traced in (but not fully determining) figures like the "general, reasonable person", which for instance is central to the concept of negligence. Hence, as already signalled, the representative reduction is not only a matter of empirical premises. The criminal law is expressing moral blame, and requires that the norm somehow in a sense is also a moral norm, however without being identical to the moral discussion and its outcome. Seen from the perspective of the representative reduction the relationship between the criminal law and morality could be expressed in the following manner:

1) From a moral point of view, the act is, as it belongs to a certain act-type, prima facie blameworthy, but the moral discussion is always open, in lack of any 
other authority than reason, therefore the prima facie judgement could be suspended by further arguments;

2) From a moral-criminal law perspective (a "Begründungsperspektive"), the act is (made) criminal because the act-type is commonly taken to be morally blameworthy;

3) From a formal legal point of view, the act is criminal as it fulfils the criteria for being a crime.

When we start out from this perspective of representative reductions and then construct a more abstract concept of the different criteria for criminal responsibility we seem to arrive at something like the legal person, or what Radbruch termed "Der Mensch im Recht": "nicht der wirkliche Mensch, sondern das Bild des Menschen, das dem Recht vorschwebt und auf das es seine Anordnungen einrichtet" ${ }^{24}$ We are different as individuals, but being a person is a distinct status in a political community. "Person" is in other words an abstract concept, or, if preferred, an abstract representative reduction of the class of individuals. It is, in the end, this status as a person which determine our protected sphere and which is the source of our legal obligations. Drawing on the etymological origin of the term, originally a term for the actor's mask, the legal concept of person is, so to speak, a mask making us basically similar to the law. ${ }^{25}$

So, the perspective of representative reductions allows us to see the concept of person in law as something more substantial than "an artificial aid of thought", as Kelsen claimed it to be, rejecting the idea of the concept of person in law as referring to some kind of pre-legal phenomenon. Already in the first edition of Reine Rechtslehre, he claimed to have cleared the way for

“... recognizing the concept of legal subject or person as simply an artificial aid to thought, a heuristic concept created by legal cognition - under the pressure of a personifying, anthropomorphic legal language - in order to illustrate the data to be dealt with. "Person" is simply a personifying expression for the unity of a bundle of legal obligations and legal rights, that is, the unity of a complex of norms. And this insight protects against the misleading hypostatizations that [in failing to distinguish between the legal and biological-psychological concepts of person] have the effect of doubling the law qua object of cognition."26

It is correct that the nexus of legal norms, with inherent representative reductions, contributes substantially to the construction of the concept of person. But still the construction of the concept of the person from the nexus of legal norms with its inherent representative reductions by necessity imports pre-legal knowledge, in the end anchoring also the legal concept of person in law in the pre-legal sphere. 
Stated differently; the legal concept of person, including its inherent pre-legal premises, is not only a means for systematising legal norms, but plays also a part in the establishing of the rule.

At the same time, we also arrive at a more concrete expression of this status than expressions sometimes found in political philosophy, for instance in Kant's definition of persons as "dasjenige Subjekt, dessen Handlungen einer Zurechnung fähig sind". ${ }^{27}$ From the point of view of criminal law; as long as we are more than 15 years old (or similar limit), not suffering from severe psychical deficits like psychosis and not being in a situation that heavily puts us under pressure, we are taken to possess a capacity of moral autonomy, i.e. to acknowledge certain basic moral principles and to control our actions in accordance with them. ${ }^{28}$ Hence, the criminal law seems in this regard to be a link between the empirical complexity of individuals and some basics principles of Western moral and political philosophy (with its own underlying complexity and contestation). In this regard, however, there seems to be a need for a mediator between law's positivity and for instance the philosophical discussion. This observation calls for some remarks concerning the role of the criminal law science, and the criminal law doctrine (Strafrechtsdogmatik) in particular, in regard to the law's operation of representative reductions.

\section{The Role of the Criminal Law Doctrine in Regard to Representative Reductions}

The criminal law doctrine is at the same time located in two distinct knowledge systems, law/criminal law and science. On the one hand, the criminal law doctrine must relate to the code of law and the positivity of legal rules when it seeks to perform its main task, the systematisation of the existing legal rules by means of conceptual systems. However, as a scientific discipline, the legal doctrine stands not only under the code of the legal system, but also under the code of the sciences: Where correctness under the code of law is to a certain extent dependent on the decision of the relevant decision makers (legislator, Supreme Court), correctness in the scientific field is defined by some universal standards of argumentation with rationality or truth as its aim. Sometimes this is seen as a problem for the legal doctrine, including the criminal law doctrine, calling for it to serve two, and at times conflicting masters.

It could, however, also be seen as a potential for the criminal law doctrine, with an obvious capacity to make complex statements that distinguish between legal and scientific "correctness" (the correct legal interpretation of the legal rule $r$ would be $r_{1}$, while the most well-reasoned solution to the legal problem, given 
an underlying theory of the criminal law, would be $r_{2}$ ). This differentiation could also be applied in regard to the representative reductions. As a legal rule, the criminal law doctrine would have to present it as it is reduced in the legal system, i.e. as valid law according to the doctrine of legal sources ( 15 years). At the same time, the criminal law doctrine, standing also under the code of science, could not, as opposed to the lawyer or judge, be content with this legal interpretation. It must also go on to inquire into whether the positive (claimed-to-be) representative reduction in fact is a representative reduction, i.e. to inquire into the pre-legal basis in order to be able to judge on the representativeness of the relevant reduction, either by own inquiries or by means of cross-disciplinary cooperation. If the positive reduction proves to be inadequate or not representative, the criminal law scientist will be obliged to add this similar to the statement above; "youths are criminally responsible from the age of 15 , however, the most well-reasoned solution to the question of responsibility of youths would, when taking recent criminological and psychological research into consideration, be to set the limit already at 13 years".

By means of such more complex statements regarding the criminal responsibility of youths, the criminal law science can interact with such surrounding fields of knowledge without disintegrating into the relevant discipline and thereby maintain its relevance to the legal system in regard to the interpretation of the current valid legal rules. Thus, the criminal law science is able to contribute to a higher level of legitimacy of the legal system. This prevents the legal concepts from becoming the "world itself" from a legal point of view - an intellectual tyranny of the legal code, and keeps the criminal law related to the life-world. This distinct transformation of knowledge into the legal system can only be performed by the legal science. Hence, Lasson's and Hagerup's emphasis on the relevance of surrounding fields of knowledge is well-argued.

\section{The Legitimacy of Criminal Law: The Problem of Injustice}

The perspective of "representative reductions" is, as just signalled, a gateway to the question of the legitimacy of criminal law. There is a manifest difference between making use of representative reductions in order to orient oneself in ordinary life, and making use of them as the basis for holding someone criminally responsible and to punish him or her. This generates the pressing problem of injustice: Could one, starting out from a personal-functional position, live with ascribing responsibility and distribute punishment from such representative reductions and their possible misconception of the relevant individual? 
First of all, this question gives us the opportunity to somewhat modify the starting point made above. The concepts of criminal law are elements in a normsystem. Even if, for instance, the level of moral development of the individual called to account is suggesting that she is not capable of being responsible, this is not necessary decisive for the formation of the norm: There is a complex relationship between "can" and "ought". A claim that "ought" presupposes "can" may be countered by Kant's words: "Daß der Mensch sich bewußt ist, er könne dieses, weil er es soll" - "That he knows he can do this because he ought to". ${ }^{29}$ A common aim of norms and norm systems, including the criminal law, is precisely to improve our behaviour where it is likely that we else would do wrong. Hence, Kant's sentence may to some extent be a proper rejection of certain kinds of less impressive (claimed-to-be) excuses. However, this does not take us very far, because what we are discussing here is in the end the capacity for "self-legislation", i.e. whether he at all knows, or can know, that he ought to do it. Also here, one might claim that for instance youths to some extent earlier come to develop their moral capacities in a community with normative expectations to them than what they would do in a community without such expectations. But here there is due to biological and psychological reasons clearly a limited potential for speeding up maturity and transgressing individual hindrances for it. And if for instance neuroscience would at some point do away with the idea of a free will as a foundational premise for responsibility, then also the criminal law would have to acknowledge this, even if it would be devastating for the entire concept of criminal law as we here have understood it. ${ }^{30}$

In the end, then, there seems to be no other solution to this problem of injustice than to point to the "functional" dimension of criminal law and the personalfunctional position, i.e. point to the fact that the criminal law is first and foremost a legal, not primary a moral phenomenon, even if these are closely related. And the legal enterprise is, in order for it to fulfil its functions as a supplement and support to morality, conditioned by the complex working premises of modern society. ${ }^{31}$ Hence, in order to have a criminal justice system that serves certain aims and which is in accordance with some basic rule-of-law-guarantees, the price we have to pay is, to put it somewhat tendentiously, to accept to be treated as persons not as individuals by the criminal justices system. The alternative seems to be to change to some kind of individualised restorative justice-solution. Here, however, there are some likely problems concerning lacking deterrent effect and the potential disregard for basic rule of law-guarantees and so on, so this is no bullet-proof alternative and not even one preferable to the modern criminal justice system. 
The negative effects of making use of functionally-motivated representative reductions could, however, be somewhat limited by emphasising the principle of optimal differentiation. The (potential) conflict or tension between a fair moral judgement of the act and the need for making use of representative reductions must, in the criminal law, be reduced by constructing the criminal law by means of morally relevant differentiations to the extent possible within the functional requirements of the code and its representative reductions. While the criminal law has less possibility to be nuanced in regard to the distinction between legal/not legal, or not criminal/criminal, it has a totally different potential for differentiation and different categorisations within the functional requirements of the legal code. The scope of the special part is one example of this ability. This principle of optimal differentiation is of fundamental importance to the concept of crime and core distinctions between completed crimes, attempts - completed attempts vs. not completed attempts - and preparatory acts, between perpetrator and accomplice and so on. ${ }^{32}$ Here, the principle of optimal differentiation is also a strong argument, for instance, for insisting on the distinction between justification and excuse found in particular in German criminal law doctrine, but unfortunately not emphasised in the Norwegian criminal law doctrine.

\section{Notes}

1. This article is part of a larger work titled Fundamentals of Norwegian Criminal Law: The Concept of Crime - A Prolegomena, to be completed in 2012. Different drafts of this text have been commented on by both participants of the research group in criminal law and criminal procedure at the Faculty of Law, University of Bergen and by participants at the conference Fundamentals of Criminal Law in Bergen. I am grateful for all comments I have received, in particular to prof. Wolfgang Frisch, prof. Heike Jung, senior lecturer Hendrik Kaptein, assistant professor Eivind Kolflaath, post.doc. Linda Gröning, research fellow Kjetil Skjerve and research fellow Ingun Fornes.

2. Faculty of Law, University of Bergen.

3. When I speak of knowledge and knowledge fields in the following, I do thereby first and foremost refer to the ambitions of these fields to acquire and represent knowledge. The limitations of this article do not allow me to go into the concept of knowledge in itself.

4. For Lasson's part, see for instance his statement that among the "most important tools" of the criminal law doctrine is "thorough knowledge of the language wherein the criminal law is drafted, together with logics, legal history, hermeneutics, knowledge of human nature or anthropology and psychology, in addition to awareness of the legal medicine (medicina forensis)", P.C. Lasson, Haandbog i Criminalretten - Den almindelige Deel (Christiania, 1848), pp. 10-11 (this and all other translations from Norwegian into English are mine). I will return to Hagerup several times below.

5. The notion of reality is complex, but will not to be discussed here. I restrict myself to say that we start out from the presupposition of some kind of "realism", i.e. that there is a 
world out there which exists regardless of our awareness or thinking of it. At the same time, this reality is of a complex nature given the fact that one adequately can speak not only of "brute" facts, but also social and institutional facts are of central importance in order to understand our "reality". The latter insight leads us towards the ideas of Emile Durkheim and John Searle (respectively).

6. See Anna Christensen: "Den juridiska mentaliteten" i E. Allardt et.al. (red.): "Mentaliteter": funderingar kring begreppet mentalitet och möjligheten av en forskning om mentalitet framförd vid en konferens $i$ Åbo 6-7 juni 1985 (Åbo, 1986), p. 88.

7. Johs. Andenæs: Alminnelig strafferett, 5. utg./Magnus Matningsdal \& Georg Fredrik Rieber-Mohn (Oslo, 2004), p. 117.

8. This seems to be a distinct legal phenomenon that does for instance not exist within morality. The right to call someone to answer for a moral wrong does not seem to be absolved alone by time passing by.

9. The terminology used is clearly influenced by the (legal) sociology of Niklas Luhmann, see in particular Das Recht der Gesellschaft (Frankfurt am Main, 1995). However, the adoption of some basic system-theoretical viewpoints and terms is not equivalent to a full acceptance of this position. Here, I start out from a somewhat modified version of this position, one that have more in common with the position of Günther Teubner, see further Jørn RT Jacobsen: Fragment til forståing av den rettsstatlege strafferetten (Bergen, 2009), see in particular pp. 201-233.

10. See for instance Dan Frände: "Om växelverkan mellan straffrätt och straffprocessrätt ur et finländskt perspektiv”, Nils Jareborg, Britta Kyvsgaard \& Per Ole Träskman (ed.): Rättsvetenskapliga studier tillägnade Vagn Greve på sextioårsdagen, NTfK (1988), pp. 221-228, rejecting the traditional view of criminal procedure as subordinate to criminal law in favor of a more complex relation here. See also Detlef Krauß: "Zur Funktion der Prozeßdogmatik", Heike Jung \& Heinz Müller-Dietz (Hrsg.): Dogmatik und Praxis des Strafverfahrens (Köln, u.a., 1989), pp. 1-14.

11. Major contributions to this discussion has been given by Jean Piaget and Lawrence Kohlberg, see for a brief overview, Charles C. Helwig \& Elliot Turiel: "Childrens's Social and Moral Reasoning", in Peter K. Smith \& Craig H. Hart: Blackwell Handbook of Childhood Development (Malden/Oxford/Victoria, 2002), pp. 475-490, pp. 475 ff., see also David R. Shaffer \& Katherine Kipp: Developmental Psychology-Childhood \& Adolescence, $8^{\text {th }}$ ed. (Belmont, 2010), pp. 584-602, including Kohlberg's list of stages of moral development and a discussion of its merits and demerits.

12. For a comparative overview, see Don Cipriani: Children's Rights and the Minimum Age of Criminal Responsibility: A Global Perspective (Aldershot, 2009), pp. 18-108 (Denmark has later lowered the age limit to 14 , Scotland has increased it to 12 years).

13. This solution had its origin in Code Pénal, see Francis Hagerup: Strafferettens almindelige del 3. udgave (Oslo, 1930), p. 239.

14. Hagerup (1930), p. 2-3 ff. makes some very brief remarks on the relation between criminal law and psychology, where he calls for some kind of import of psychological knowledge, at the same time as he maintains so to speak the autonomy of the field of criminal law in regard to psychology as a science. 
15. The, to the term "reduction" closely related, notion of "reductionism" is a debated subject in philosophy and in particular in the philosophy of science, se for an brief overview Paul Teller: "Reduction" in Robert Audi (red.): The Cambridge Dictionary of Philosophy, $2^{\text {nd }}$ edition (Cambridge, 1999). At this stage, I do not imply a particular reference to this discussion.

16. Andenæs (2004), p. 295, my translation, outlined here.

17. Per Ole Träskman: "Strafflagen för den Europeiska union - Fakta och fiktion", SvJT (2001), pp. 345-362, p. 355.

18. H.L.A. Hart: "Prolegomenon to the Principles of Punishment", in: H.L.A. Hart: Punishment and Responsibility - Essays in the Philosophy of Law (Oxford/New York, 1968), pp. 1-27, p. 19.

19. See paradigmatic, Immanuel Kant: Die Metaphysik der Sitten [1797] in: Wilhelm Weischedel (Hrsg.), Immanuel Kant, Werke in sechs Bänden, 6. unveränderte Auflage (Darmstadt, 2005), Band IV, p. 453.

20. In regard to the example used, there are also other "symbolic" social institutions that probably make their impact here. One could for instance remind of the ritual of Christian confirmation, which (at least in Norway) does not only have religious meaning, but is also a social ritual for "entrance to adulthood" - at the age of 15 .

21. Unsuccessful (claimed-to-be) representative reductions should however be distinguished from what one may term overridden representative reductions. For instance, some legal rules make it criminal for one to create smaller risk than what kinds of risk-level people in general are able to control and/or that generate blame (for instance driving with $0,002 \%$ alcohol in the blood) Here, it is symbolic arguments ("zero tolerance") that override the representative reduction. This overriding, or risk-minimizing, does however necessitate a critical discussion of the forming of the act description and seeing it precisely in the perspective of the representative reduction is helpful in regard to articulating the problem even if the concept of a representative reduction does not solve the problem at stake. This allows us to first, underline that the notion of representative reductions is not meant as an all-inclusive explanation of the criminal law, but only one central dimension of it. Also, and more specific, it gives the opportunity to note that the so-called offences of "abstract danger-creation" can be seen as one specific example of representative reductions.

22. See NOU 1990: 5, Strafferettslige utilregnelighetsregler og scerreaksjoner. Straffelovkommisjonens delutredning $I V$. I here disregard the discussion on whether this revision was in fact successful.

23. It should, however, be added that this is often a problem stemming from not the intellectual frontrunners of such movements, but rather from the disciples, with less intellectual discipline, of these frontrunners.

24. Gustav Radbruch, "Der Mensch im Recht", in: Gustav Radbruch: Der Mensch im RechtAusgewählte Vorträge über Grundfragen des Rechts (Göttingen, 1957), pp. 9-22, p. 9.

25. See further Adolf Trendelenburg: "Zur Geschichte des Wortes Person", Kant-Studien (1908), p. 3-17 and Dieter Struma: Philosophie der Person: Die Selbstverhältnisse von Subjektivität und Moralität (Paderborn, 2008), pp. 44-57. 
26. Hans Kelsen: An Introduction to the Problems of Legal Theory - translated by Bonnie Litschewski Paulson and Stanley L. Paulson with an Introduction by Stanley L. Paulson (Oxford, 1992), pp. 46-47.

27. ... Struma (2008).

28. See also Hagerup's remarks concerning "normal human beings", Hagerup (1930), for instance pp. 237-238.

29. See Immanuel Kant: Über den Gemeinspruch: Das mag in der Theorie richtig sein, taugt aber nicht für die Praxis [1793], in: Wilhelm Weischedel (Hrsg.): Immanuel Kant, Werke in sechs Bänden, 6. unveränderte Auflage (Darmstadt, 2005), Band VI, p. 142, English translation is taken from Immanuel Kant: On the Old Saw: That May Be Right in Theory but it won't Work in Practice, Translated by E.B. Ashton, Introduction by George Miller (Philadelphia, 1974), p. 54. I add that the meaning of the inference of ought to can (which, as for instance Joachim Hruschka has pointed to, does not have it origin in Kant's works) is not easily grasped, and it has also received different interpretations and forms, see further Joachim Hruschka, "Imputation", Brigham Young University Law Review (1986), pp. 669-710, pp. 674-676.

30. Neuroscience seems so far at least not to have given us a reason to call off the idea of free will, see Jürgen Habermas: "Freiheit und Determinismus", in Jürgen Habermas: Zwischen Naturalismus, Religion und Philosophische Aufsätze (Frankfurt am Main, 2005), pp. 155186. And it remains problematic if this insight at all could be reached, see for instance Hruschka (1986), p. 704-710, see also Hans J. Hirsch: "Zur gegenwärtigen deutschen Diskussion über Willensfreiheit und Strafrecht”, ZIS (2010), pp. 62-67.

31. Hagerup can be taken to have held a similar position when claiming that "a legal rule that relates the acquisition of legal capacity (age of majority) or of the right to vote and eligibility for office conditioned by a certain age, cut across the several individual differences that conditions different maturity by different individuals at the same age. Such a legal rule will thereby confront the requirement of justice concerning what is different should not be treated equally; but anyone will easily see that a uniform, clear and unambiguous rule is at this point necessary", see Francis Hagerup: Forelasninger over retsencylopcedi (Kristiania, 1906), p. 13.

32. This way of approaching concepts is not a new invention; for instance Aristotle motivated his separation of the non-voluntary agent from both the voluntary and the involuntary by saying that "since he differs from the other, it is better that he should have a name of his own", see Aristotle: Ethica Nichomachea, translated by W.D. Ross, printed in Richard McKeon (ed.): The Basic Works of Aristotle (New York, 2001), p. 927-1126, 1110 b. 